
\title{
25 Research Suare \\ The Analysis of Pre-Monsoon Dust Storm Over Delhi Using Ground Based Observations
}

avinash parde

IITM: Indian Institute of Tropical Meteorology https://orcid.org/0000-0001-5158-3187

\section{Prakash Pithani}

IITM: Indian Institute of Tropical Meteorology

\section{Sachin D. Ghude ( $\sim$ sachinghude@tropmet.res.in )}

IITM: Indian Institute of Tropical Meteorology

\section{Narendra G. Dhangar}

IITM: Indian Institute of Tropical Meteorology

\section{Chinmay Jena}

IITM: Indian Institute of Tropical Meteorology

D.M. Lal

IITM: Indian Institute of Tropical Meteorology

\section{Gopal Krishna}

IITM: Indian Institute of Tropical Meteorology

\section{Research Article}

Keywords: Dust storms, Vertical dust distribution, Floating layers, Ceilometer, WiFEX

Posted Date: March 11th, 2021

DOI: https://doi.org/10.21203/rs.3.rs-255386/v1

License: @ (i) This work is licensed under a Creative Commons Attribution 4.0 International License. Read Full License

Version of Record: A version of this preprint was published at Natural Hazards on February 11th, 2022. See the published version at https://doi.org/10.1007/s11069-022-05207-z. 


\section{Abstract}

Three major sequential widespread dust events were experienced in the northern parts of India in May 2018. A significant impact of these pre-monsoon dust storms on the aerosol characteristics over the Indian National capital region (NCR) has been studied using remotely sensed ceilometer and groundbased measurements at Indira Gandhi International (IGI) airport, New Delhi, India. From the results, it is noticed that after each consecutive dust activity, the significant inclusion of dust aerosols loaded in the Free Troposphere (FT). Consequently, the direct impact on the lower atmospheric parameters like increase in daily average temperature (by 4-5 K), stepped up (stepped down) diurnal cycles of longwave fluxes (shortwave fluxes) has been recorded within 15 days of dust span. Mainly, the adverse meteorological and radiation features noticed before first dust storm (DS1), which pinpoints the sudden intrusion of dust over NCR, Delhi. However, this dust storm has extensively impacted in terms of the vertical dust loading, surface boundary layer mechanisms, and socioeconomic way. Therefore, the detailed analysis of vertical dust distribution and its interaction with middle tropospheric processes has been carried by using the vertical normalized attenuated backscatter coefficients accompanying the radiosonde observation. The aloft floating dust layer up to 3-4 km has been noticed even after shallow rainfall and persisted at almost the same height for the next 34 hrs due to low-level clouds. Meanwhile, the sub dust layer below 1 $\mathrm{km}$ is formed due to local activity, which also sustains for a long time. Moreover, the cumulative losses in terms of the impediment in airline operations (delay and diversion), live causalities, and deaths were estimated at US\$1.3 million over these dust period.

\section{Introduction}

Sand and dust storms (SDS) are high-impact and lower atmospheric phenomenon that occur in different parts of the world (Kohfeld et al., 2001; Ginoux et al., 2012; Shepherd et al., 2016). Notably, they develop over the arid and semi-arid regions, caused by intense surface heating and steep atmospheric pressure gradients. These correlated terms lead to form an extreme wind erosion that rolls up an ample amount of sand and dust particles from bare, dry, and unconsolidated surfaces into the atmosphere (Blanco-Canqui et al., 2010; Shepherd et al., 2016). The coarse dust particles in the atmospheric boundary layer blow short distances (Hara et al., 2009). However, the wind circulation in the Free Troposphere (FT, mainly the layer above $3 \mathrm{~km} \mathrm{PBL}$ is FT) transports the fine dust particles over long distances, even across continents (Husar et al., 2001; Goudie et al., 2006; Uno et al., 2009; Kaskaoutis et al., 2012). Dust loading in the northern hemisphere is significantly high, mainly due to the deserts and adjoining areas of Africa Asia continent (Sivaprasad et al., 2017). Furthermore, the dust storms over the northwestern part of the Indian subcontinent, especially over the Thar Desert, are leading dust source in south Asia (Pandithurai et al., 2008; Badarinath et al., 2010). Meanwhile, during the dry pre-monsoon season (April-June), the dust outflow from these regions carried by westerly southwesterly winds enhances the aerosol loading over the Indo-Gangetic Plains (Sikka et al., 1997; Dey et al., 2004; Prasad et al, 2007b; Kedia et al., 2011; Verma et al., 2013; Kumar et al., 2015). 
Moreover, the adverse impact of dust aerosols loading in the atmosphere has been seen globally, either directly or indirectly, on different aspects. For instance, dust aerosols directly influence the atmospheric radiative budget by scattering and absorbing radiation fluxes including both Shortwave (SW) and Longwave (LW) radiation, and indirectly affecting the cloud microphysics (Twomey et al., 1977; Albrecht et al., 1989; Miller et al., 2004). However, the long term effects of SDS have been noticed on monsoon, hydrological cycle, climate, human health, environment, and socio-economic activities (Ramanathan et al., 2001; Kayetha et al., 2007; Miri et al., 2009; Mahowald et al., 2010; WHO, 2013; Middleton, 2017; Pandey et al., 2017). Therefore, studies of SDS will significantly benefit the understanding of the role of the aerosol particles in various atmospheric mechanisms.

The primary research approaches for dust storms study includes remote sensing monitoring and groundbased observations. With wide coverage and dynamic observation, space-borne technology has been usually preferred for monitoring, tracking, and nowcasting SDS (Prospero et al., 2002; El-Askary et al., 2006; Gautam et al., 2009; Ginoux et al., 2012; Kaskaoutis et al., 2012; Gharai et al., 2013). A recent study by Sarkar et al., (2019) based on satellite and ground-based observational data illustrates that the sudden drop in the surface temperature enhances upper-air humidity and corresponding shifting in radiation balance enhances the movement of greenhouse gases (03 and $\mathrm{CO}$ ) in the middle-upper troposphere during each dust event in May 2018. However, the dust aerosol vertical distribution and their interlinkage with prevailing boundary layer phenomena were missing in this study. Moreover, limited temporal satellite observation, complex landscapes structure, and the diversity of dust characteristics has hindered spacebased technology to develop a deep understanding of SDS and later the residual dust role in atmospheric processes.

Therefore, ground-based LIDAR networks are crucial in studying SDS temporal evolution, non-local dust transports and help connect the link of remnant dust aerosols study in the physicochemical research (McGowan et al., 2012; Mona et al., 2012). The ceilometer has traditionally been only used to report the cloud base height, cloud depth, and vertical visibility. Nowadays, several studies have shown that the ceilometer backscatter product is also useful for estimation of cloud fraction, dust intrusion and aerosol layer height, approximate particulate mass concentration $\left(\mathrm{PM}_{10}\right.$ and $\left.\mathrm{PM}_{2.5}\right)$, and volcanic ash (Illingworth et al., 2007; Münkel et al., 2007; Nemuc et al., 2014; Parde et al., 2019). Moreover, the LIDAR's and most recent generation ceilometers have been used in network to produce accurate and long-term measurements of aerosol properties, their interaction with cloud layers, and relevant meteorological applications (Murayama et al., 2001; Welton et al., 2001; Boesenberg et al., 2003; Bösenberg \& Hoff, 2007; Kawai et al., 2018, 2019). But, considerably very limited study has been reported in the context of spatiotemporal dust storms analysis based on an automated single-wavelength ceilometer.

The present study investigates the deadly dust storm events using the backscatter product of state of the art ceilometer and extensive surface meteorological observations at the Indira Gandhi International (IGI) airport, New Delhi, India, during May 2018. The capabilities of the Lufft CHM 15k Nimbus ceilometer using high-temporal vertical aerosol backscatter profiles have been analysed and used to describe the dust aerosol activities before, during, and after the dust storm event. The geographical and climatic 
conditions of the study area and observational datasets are presented in Sect. 2. And, the integral analysis of dust storms and their socioeconomic impacts are comprehensively described in Sect. 3.

\section{Observational Site And Datasets}

The Winter Fog Experiment (WiFEX) observational site is located at IGI airport, where this airfield is surrounded by industrial and urban areas and encompasses nearly 2,066 hectares ( 5000 acres); in New Delhi, India $\left(28.55^{\circ} \mathrm{N}, 77.09^{\circ} \mathrm{E}, \mathrm{MSL}\right.$ of $229 \mathrm{~m}$, Fig. 1). Furthermore, the National Capital Region (NCR), Delhi, lies in the landlocked Northern Plains of the Indian subcontinent, surrounded by the Himalayas in the north, the Thar Desert in the west, and the hot plains of central India in the south. Consequently, NCR Delhi witnesses to extreme weather conditions like scorching summers and relatively cold winters from the decades (Pai et al., 2013; Ghude et al., 2017).

In order to gather the information of prevailing weather parameters across such extreme events, a wide range of instruments, including a ceilometer, $20 \mathrm{~m}$ flux tower (equipped with multi-meteorological sensors), and PM sampler, has been operationalized during pre-monsoon dust activity occurred within a period of 15 days in May 2018. Here, entire observational datasets have been represented in the Indian Local Standard Time (LST: UTC + 5:30). The Lufft CHM 15k Nimbus ceilometer (1064 nm) installed on the roof (7 $\mathrm{m}$ Above Ground Level (AGL)) of the observatory instruments lab, has recorded Attenuated Backscatter Coefficient (ABC). Additionally, the diurnal variations of meteorological parameters like wind vector, air temperature, relative humidity, and precipitation have been recorded with the help of the multicomponent weather sensor WXT 520 (Vaisala Oyj). Also, the Net radiometer at $2 \mathrm{~m}$ height from the ground is collocated with other instruments used to record Radiation fluxes (longwave and shortwave radiation). Throughout this study, 1 min high temporal resolution meteorological parameters along with these radiative fluxes have been analyzed by taking an hourly average. Moreover, the particulate matters $\left(\mathrm{PM}_{10}\right.$ and $\left.\mathrm{PM}_{2.5}\right)$ over the study site (nearly $0.8 \mathrm{~km}$ away from the ceilometer) have been monitored by the Central Pollution Control Board (CPCB) using the PM sampler. This 60 min averaged PM concentration followed the beta attenuation method. The planetary boundary layer height (PBLH) and vertical thermodynamic structure were derived at two distinct time intervals by employing radiosonde ascent data (http://weather.uwyo.edu/upperair/sounding.html) from the Ayanagar, New Delhi (nearly 10 $\mathrm{km}$ far from the observational site).

\section{Methodology}

The raw datasets i.e. $A B C$ values (vertical and temporal resolution of $15 \mathrm{~m}$ and $15 \mathrm{~s}$ ) which retrieved from ceilometer NetCDF files have been normalized below $15 \mathrm{~km}$ and generated backscatter plots up to $5 \mathrm{~km}$ altitude. Additionally, 30 min averaged $A B C$ values have been evaluated for accurate quantification of vertically distributed dust structure. The more technical details about the Lufft CHM 15k Nimbus ceilometer and the response of their $A B C$ values to primary pollutants $\left(\mathrm{PM}_{10}\right.$ and $\left.P M_{2.5}\right)$ has already been validated in Parde et al., (2019). However, in order to estimate of PBLH from radiosonde profiles over 
Delhi during the entire dust period, we followed the PBL mixing height method mentioned in Aryee et al., (2020).

\section{Results And Discussion}

\section{Socioeconomic losses during Dust events of May 2018}

The devastating dust storm in northern parts of India especially, Uttar Pradesh, Bihar, Delhi, and Rajasthan in May 2018 is listed among 35 extreme weather events caused by the climate changed, mentioned in 'The Global Climate in 2015-2019' report released by the WMO. The first, deadly severe dust storm (claimed more than 125 deaths and over 200 injuries) hit India's northern states on 2-3 May 2018. Subsequently, the second (7-8 May 2018) and third (12-13 May 2018) dust storm have reported fewer socioeconomic annihilation and casualties. SDS affect the different segments of an economy, either directly (immediate consequences of events) or indirectly (secondary outcomes that may occur after direct effects) (Al-Hemoud et al., 2019). As, the direct effects consider detrimental health consequences, human and livestock causalities/deaths, road accidents, airline delays/diversions/cancellations, uprooting of trees and crops, damages of residential premises, and electrical house/poles.

As per available record from the different airbases of northern parts of India during May 2018, more than 70 flights were diverted, and dozens of flights were delayed. On the other hand, state governments had declared 5,642 USD (400,000 INR) will be given to family members of deceased, and around 2,821 USD ( 200,000 INR) to persons sustaining 40-60\% injuries. In order to evaluate gross economic loss to airlines, the breakdown charges for different segments of flight operations was obtained from the Center for Asia Pacific Aviation (CAPA) of India and Indian Civil Aviation Ministry (Kulkarni et al., 2019). Therefore, based on the abovementioned information and records, the cumulative losses have been evaluated. Here, the diversion and delay of flights collectively caused an economic loss of approximately 0.55 million USD (36.86 million INR). However, the cumulative losses in terms of the impediment in airline operations (delay and diversion), live casualties and deaths have been estimated at US\$1.3 million (86.75 million INR), over these dust episodes. Particularly, this estimated loss based on these two aspects are approximately equal to $1-2 \%$ of the total destruction cost that occurred due to dust episodes in May 2018 in the northern part of India.

\section{Prevailing Meteorology during Dust events of May 2018}

Figure 2 showed, the satellite images of these dust plumes persisting over the IGP region which have been retrieved from NASA Earth Observing System MODIS-Terra platform (https://worldview.earthdata.nasa.gov) for 02 May, 07 May, and 13 May in 2018, respectively. Moreover, the spatial sweep of dust carried from Pakistan, the Arabian Peninsula, and the Thar Desert has been clearly depicted in Sarkar et al., 2019. Even if this dust plumes are not seen thick enough in satellite images but it has deteriorated the air quality of urban and rural areas drastically. In order to reconfirm these dust events, hourly averaged diurnal variation of particulate matters along with the influential surface meteorological drivers have been examined, which is represented in Fig. 3. 
First intense dust storm DS1 (represent by the shaded patch) hit the observational site on 02 May 2018 around 17:00 - 18:00 LST, resulting in a significant increase in PM concentration. From Fig. 3(a), first peak (DS1) of $\mathrm{PM}_{10}\left(\mathrm{PM}_{2.5}\right)$ concentration at IGI airport suddenly increased ( 4 times) from 138 (55) $\mu \mathrm{g}$ $\mathrm{m}^{-3}$ at 16:00 - 17:00 LST to $528(106) \mu \mathrm{g} \mathrm{m}^{-3}$ at 17:00 - 18:00 LST. Subsequently, during the second (DS2) and third dust storms (DS3), gradually increased in $\mathrm{PM}_{10}\left(\mathrm{PM}_{2.5}\right)$ concentration from 354 (96) $\mu \mathrm{g}$ $\mathrm{m}^{-3}$ at 22:00 LST to $776(101) \mu \mathrm{g} \mathrm{m}^{-3}$ at 23:00 LST on 07 May 2018, and $182(79) \mu \mathrm{g} \mathrm{m}^{-3}$ at 15:00 LST to $335(80) \mu_{g^{-3}}$ at 16:00 LST on 13 May 2018. Similar kind of sharp peaks in particulate matter mass concentrations ( 2 - 50 times of its control values) within the short periods have been noticed over the Gobi Desert by Jugder et al. (2014) and Kawai et al. (2019). Succinctly, an abrupt rise in given particulate matter concentrations, indicates the potency of these dust storms.

Frequently, the PBLH extend up to $2-3 \mathrm{~km}$ over the northern part of the Indian subcontinent during the summertime period as a result of intense solar heating (Patil et al., 2013). Nevertheless, Fig. 3(a) clearly demonstrate, the uplift and vertical extent of dust mainly influenced by the surface meteorology within the atmospheric boundary layer which could stretch PBLH above $3 \mathrm{~km}$. Moreover, the diurnal variation of $\mathrm{PBL}$ is the response of radiation, winds and energy balance. In the early mornings (05:30 LST), the stable boundary layers at calm wind condition persisted below 500 m AGL. In contrast, convective boundary layer heights around late afternoons (17:30 LST) ranged between $1000 \mathrm{~m}$ AGL and $3800 \mathrm{~m}$ AGL, pointing toward colossal vertical mixing. Meanwhile, prior to each dust storms, a dry atmospheric agreement lower atmosphere has been noticed which is conclude from $20-30 \%$ reduction in $\mathrm{RH}$ values during maximum temperature range (Fig. 3(b)). On the other hand, convective instability is built up during each dust events through an increase in low level moisture (by $30-40 \%$ ) corresponding to rapid fall down in temperature (about $10 \mathrm{~K}$ ) in 6 hours of interval. In addition, a sudden shift in wind vector shown in Fig. 3(c), has conferred to vertical dust mixing/turbulent activities.

However, these suddenly impacted dust storms directly affected the radiative fluxes which could be clearly analysed by comparing it's diurnal variations obtained a day prior to dust storm (Solid line), during the dust storm (Symbolic line), and the day after the dust storm (Dash line) reported in Fig. 4. Generally, in most of the dust storm cases worldwide, it has been observed that longwave flux (includes both Incoming and Outgoing) values one day before (one day after) dust activity are high (less) as noticed in DS2 and DS3 event depicted in Fig. 4(a) and Fig. 4(b). Interestingly, the opposite result seems in the case of DS1, where dust day shows trivial raised in longwave fluxes compared to the former day. Concisely, the sudden subsidence of non-local dust over NCR, Delhi without a prior day warming, could be a reason for that. The gradually increased diurnal values of longwave flux before each dust episodes show additional radiative energy has caused a warming of the lower atmosphere. Afterwards, the Incoming longwave flux; significantly decrease from its peak within an hour during DS1 (from 468 to $439 \mathrm{~W} \mathrm{~m}^{-2}$ ), DS2 (from 470 to $448 \mathrm{~W} \mathrm{~m}^{-2}$ ), and DS3 (from 495 to $450 \mathrm{~W} \mathrm{~m}^{-2}$ ). Additionally, such rapid fall in the percentage of Outgoing longwave flux $(6 \%, 5 \%$, and 10\%) along with minor cut off in shortwave fluxes (includes both Incoming and Reflected) due to these huge dust intrusion in a short time could yield the cool next hours/days relative to preceding warmer hours/days. The increased daily mean of surface temperature 
(by 4-5 K within 15 days dust span), stepped up (stepped down) diurnal cycles of longwave fluxes (shortwave fluxes) from DS1 to DS3 are utter pinpoints that after each consecutive dust activities, the inclusion of dust aerosols has loaded in FT.

However, in order to reveal these meteorological and radiative features associated with dust activities in pictorial form, the ceilometer backscatter profiles have been combined and analysed for the same dust span. Figure 5, shows the time-height cross-section of the ceilometer aerosol $A B C$ in $\mathrm{m}^{-1} \mathrm{sr}^{-1}$ from 01 May 2018 to 16 May 2018. In that, green and brown shades represent aerosol top layers and cloud bottom layers. From the ceilometer backscatter profile it has been disclosed that the residual dust layers after each dust episodes (DS1, DS2, and DS3) were extended vertically to the FT. For evidence, the small angstrom exponent corresponding to higher Aerosol Optical Depth at $550 \mathrm{~nm}\left(\mathrm{AOD}_{550}\right)$ indicated a significant increase in aerosol loading, especially in the coarse mode in FT (D. Lal et al., 2018; Sarkar et al., 2019). Often, after the dust episodes the elevated columnar water vapour in the upper troposphere has been observed which further leads to cause the thunderstorms/rainy activities over IGP and part of northwest India (Dey et al., 2004; Prasad and Singh, 2007a, 2007b). These events are usually short and sporadic. Likewise, four scatter rainfall events RF1 (2.5 mm), RF2 (0.2 mm), RF3 (1.6 mm), and RF4 (6.7 $\mathrm{mm}$ ) at IGI airport has been recorded. Particularly, the rainfalls after DS1 and DS3 event are associated with WDs which bring ample amount of moisture and maintain low level clouds, especially over NCR which are depicted in Fig. 2(a), Fig. 2(c) and Fig. 5. Additionally, it has been noticed in ceilometer backscatter profile that the RE4 after DS3 was relatively strong enough to washout floating dust and pollution in the atmosphere which was specifically persisted in FT after DS1. By considering comprehensive facts of all dust episodes in terms of socioeconomic impact, prevailing meteorology, and direct and indirect repercussion of radiative fluxes, the detailed analysis of DS1 has been carried out.

\section{Vertical dust distribution and its peculiarities - Before Dust Storm (DS1)}

Time-height cross section of ceilometer backscatter profile and surface meteorological observations at IGI airport illustrated in Fig. 6 for thorough analysis of DS1. In addition, Table 1demonstrates the variations in half-hourly averaged $A B C$ values within two vertical heights $(0-0.5 \mathrm{~km}$ and $0.5-1 \mathrm{~km})$ corresponding to prior, during, and after the dust storms and posterior to rain events, respectively. Similarly, for the same time variations in half-hourly averaged vertical attenuated backscatter profiles for the DS1 event represented in Fig. 7.

The residual aerosol layer between 2-3 km height and low aerosol concentrations in FT during a stable night period has represented in Fig. 6(a). However, the aerosol backscatter signals, wind speed, and the temperature gradually increased in morning hours (06:00 LST) of DS1 event. During this cloud-free daytime, the maximum hourly averaged temperature of $36.37^{\circ} \mathrm{C}$ is recorded $1 \mathrm{hr}$ before the DS1 (between 16:00 LST to 17:00 LST), indicates the local convection. Therefore, the depth of aerosols layers nearly 1$2 \mathrm{~km}$ in the daytime period, is mainly influenced by local convective instability and turbulent venture. This turbulence in the mixed layer is convectively driven. 
Moreover, in Fig. 6, the vertical ceilometer backscatter profile shows the turbulent activity is more dominant within $1 \mathrm{~km}$ before the dust storm event. From Table 1 and Fig. 7, it has also been noticed that the half-hourly averaged $A B C$ value from 16:10-16:40 LST (20 min before DS1) within $0.5 \mathrm{~km}$ of the boundary layer $\left(0.73 \times 10^{-6} \mathrm{~m}^{-1} \mathrm{sr}^{-1}\right)$ recorded slightly less than $A B C$ value $\left(0.80 \times 10^{-6} \mathrm{~m}^{-1} \mathrm{sr}^{-1}\right)$ within $0.5-1 \mathrm{~km}$. During the clear day, unstable conditions might have created strong winds and vertical convection, which created the vertical aerosol mixing. However, these unstable conditions and convective eddies during the daytime period cause non-local transport above the mixed layer. The gradually increasing scattered vertical backscatter profile (black line) after $2 \mathrm{~km}$ also shows the non-local dust transport over the IGI airport.

Table 1

Variations in half-hourly averaged attenuated backscatter coefficient on 02 May 2018 corresponding to prior, during, and posterior of the dust storm and after a rainfall event within $0-0.5 \mathrm{~km}$ and $0.5-1 \mathrm{~km}$ height.

\begin{tabular}{|lll|}
\hline Dust Activity & \multicolumn{2}{l}{ Attenuated Backscatter coefficient in $\mathbf{~}^{-1} \mathbf{~ s r}^{-1}$} \\
\cline { 2 - 3 } & $\mathbf{0 - 0 . 5} \mathbf{~ k m}$ & $\mathbf{0 . 5 - 1} \mathbf{~ k m}$ \\
\hline Before DS1 (16:10-16:40 LST) & $0.73 \times 10^{-6}$ & $0.80 \times 10^{-6}$ \\
\hline During DS1 (17:00-17:30 LST) & $5.63 \times 10^{-6}$ & $0.45 \times 10^{-6}$ \\
\hline After DS1 (17:30-18:00 LST) & $2.40 \times 10^{-6}$ & $0.64 \times 10^{-6}$ \\
\hline After Rain (20:30-21:00 LST) & $0.28 \times 10^{-6}$ & $0.16 \times 10^{-6}$ \\
\hline Cal duSt distribution and its peculiarities - During Dust \\
(DS1)
\end{tabular}

Several stability indices such as Convective Available Potential Energy (CAPE), Lifted Index (LI), Severe Weather Threat Index (SWEAT) based on radiosonde data during the 02 May 2018 dust storm (17:30 LST) have calculated from the Radiosonde profile. Maximum values of CAPE (2696 $\mathrm{J} \mathrm{kg}^{-1}$ ) and SWEAT (406.39) along with highly negative lifted index (-8.98), indicates a strong convective forcing and thermal turbulence over New Delhi during DS1. On the same day, after recording the maximum temperature at 16:00 LST over the IGI airport, continuously dropping surface temperature over $6 \mathrm{hrs}$ of period indicates radiative cooling at the surface. In two hours (from 16:00 LST to 18:00 LST), the surface temperature dropped by $6.2 \mathrm{~K}$. Meanwhile, the significantly high $A B C$ value $\left(5.6 \times 10^{-6} \mathrm{~m}^{-1} \mathrm{sr}^{-1}\right)$ represent intense dust activity within $0.5 \mathrm{~km}$ from 17:00 LST to 17:30 LST due to the convective activity. However, the small $A B C$ value $\left(0.45 \times 10^{-6} \mathrm{~m}^{-1} \mathrm{sr}^{-1}\right)$ between $0.5-1 \mathrm{~km}$ heights represents the shallow dust layer during the same period. From Fig. 7, the vertical backscatter profiles difference between prior (black line) and during (red line) DS1 demonstrates positive values, especially above $0.5 \mathrm{~km}$. Also that, sharply decreasing vertical backscatter profiles (shown in Fig. 7 by a red line) comparing with increasing 
vertical relative humidity (shown in Fig. 8(a) by a blue line) up to $1-1.5 \mathrm{~km}$ during DS1 indicates frequently wet deposition of the upper-level dust in the lower level.

The half-hourly average $A B C$ value within a height of $0.5 \mathrm{~km}$ increased by about 7.3 times over $1 \mathrm{~min}$ from 17:00 LST to 17:01 LST. In this case, the $A B C$ values within $0.5 \mathrm{~km}$ height suddenly increased over a few min of intervals. Also, the sharp dropdown in ABC within $0.5-1 \mathrm{~km}$ height shows the sudden impact of developed dust storms at IGI airport, Delhi. However, this dust storm is developed somewhere before reaching to the observational site. A similar result was noticed by Kawai et al. (2019) during the ceilometer observation of dust event in the Gobi Desert on 29-30 April 2015. We also noticed a positive relation between a dust storm and wind speed like the previous study by Kawai et al., 2019. The hourly averaged wind speed recorded $6-8 \mathrm{~m} \mathrm{~s}^{-1}$, and the wind direction suddenly rotated from southwest to northeast during DS1.

\section{Vertical dust distribution and its peculiarities - After Dust Storm (DS1)}

The surface wind speed is rapidly turbulent $\left(8-9 \mathrm{~m} \mathrm{~s}^{-1}\right)$, which enhanced the dust mixing in the boundary layer and reduce its concentration at the surface. The half-hourly averaged $A B C$ value recorded at the surface just after dust storm $\left(2.40 \times 10^{-6} \mathrm{~m}^{-1} \mathrm{sr}^{-1}\right)$ was 2.34 times less compare to $A B C$ during a dust storm $\left(5.63 \times 10^{-6} \mathrm{~m}^{-1} \mathrm{sr}^{-1}\right)$. However, the values within the height of $0.5-1 \mathrm{~km}$ slightly increased $(0.45$ $\times 10^{-6}-0.64 \times 10^{-6} \mathrm{~m}^{-1} \mathrm{sr}^{-1}$ ) over half an hour from 17:30 LST to 18:00 LST on 02 May 2018. This $A B C$ values corresponding to the dust was relatively increased above $0.5 \mathrm{~km}$ height, indicating the strong vertical mixing. Therefore, ascending air should have updraft dust particles and extend it nearly $3-4 \mathrm{~km}$ high from the dust storm to the floating dust layer's height. The vertical structure of this floating dust layer (extended almost $4 \mathrm{~km}$ ) represented in Fig. 7 (green line) shows more dust concentration than the DS1 period (red line) above $0.5 \mathrm{~km}$ height. However, from the ceilometer backscatter profile depicted in Fig. 5 the height of this floating dust layer persisted almost unchanged for the next $34 \mathrm{hrs}$.

Meanwhile, the floating dust layer reached the FT and mixed with clouds. From $10 \mathrm{~km}$ ceilometer backscatter profile (not given here), it is observed that cloud base height decreased from $8 \mathrm{~km}$ at 17:40 LST to $2 \mathrm{~km}$ at 19:00 LST. Later, two scatter rainfall events viz. RE1 and RE2 were recorded after the dust storm DS1. The RE1 and RE2 occurred within intervals of $2 \mathrm{hrs}$ and $34 \mathrm{hrs}$ from the dust storm period. These two scatter rainfall results from the western disturbances, floating dust layer and its interaction with cloud, which is clearly depicted in Fig. 2 and Fig. 5. Also, Kawai et al. $(2018 ; 2019)$ noticed the same results of floating dust layer mixing with clouds after the dust events in the ceilometer backscatter profile. Rain, cloud base and cloud depth are represented by large $A B C$ value $\left(>9.0 \times 10^{-6} \mathrm{~m}^{-1} \mathrm{sr}^{-1}\right)$. Figure 6(a) and 6(c), illustrates the onset of first scatter rainfall RE1 noticed after DS1 which started to precipitate (0.9 $\left.\mathrm{mm} \mathrm{hr}^{-1}\right)$ at 19:40 LST and its peak $\left(2.5 \mathrm{~mm} \mathrm{hr}^{-1}\right)$ at 20:30 LST on 02 May 2018. Gusty winds, cloudy conditions, and scatter rains led to a significant drop in the ambient temperature by $4-5 \mathrm{~K}$ within $2 \mathrm{hrs}$ (19:00 LST - 21:00 LST). 


\section{Vertical dust distribution and its peculiarities - After Rain}

In a period of 03:30 hrs (between red and blue profiles), the $A B C$ values underneath of $0.5 \mathrm{~km}$ sharply reduced by 20 times to dust time $A B C$ values $\left(5.63 \times 10^{-6} \mathrm{~m}^{-1} \mathrm{sr}^{-1}\right.$ to $\left.0.28 \times 10^{-6} \mathrm{~m}^{-1} \mathrm{sr}^{-1}\right)$.

After the scatter rainfall RE1, the $A B C$ values (blue line, less than $0.5 \times 10^{-6} \mathrm{~m}^{-1} \mathrm{sr}^{-1}$ ) became lower than dust event values (red line) below $1 \mathrm{~km}$ height. Meanwhile, the primary pollutant namely, $\mathrm{PM}_{10}\left(\mathrm{PM}_{2.5}\right)$

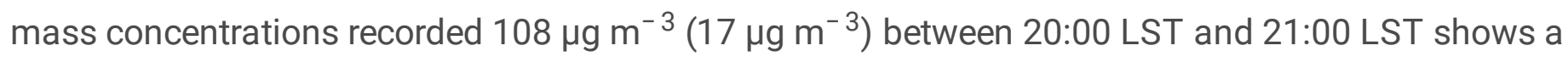
drastic improvement in air quality. Surprisingly, raised $A B C$ values in blue profile above $1 \mathrm{~km}$ represents that floating dust load was still remained above $1 \mathrm{~km}$ of lower atmosphere. However, the floating dust around the height of 3-4 km AGL was persisted almost for $34 \mathrm{hrs}$ from the time of DS1 depicted in Fig. 5. The horizontal spike (higher $A B C$ values) in blue profile above 4 resulted from high response of $A B C$ to low level moist clouds which cross verified from cloud base height of ceilometer product. Therefore, the presence moist low level clouds trapped floating dust underneath of $4 \mathrm{~km}$ height and avoided to extend it into the FT. The secondary shallow dust layer formed underneath of floating dust layer correspond to different dust source after 9 hrs intervals of RE1. This lower sub dust layer within $1 \mathrm{~km}$ is generated from the local dust pollutants, while the overhead floating dust layer within $4 \mathrm{~km}$ was residual part of the dust storm DS1.

From the radiosonde profile at 05:30 LST on 03 May 2018 shown in Fig. 8(b), the number of interesting facts has been noticed. In particular, (1) the strong inversion (ground level values missing up to $200 \mathrm{~m}$ ) of $6.8^{\circ} \mathrm{C}$ under the potential temperature gradient of $19.67 \mathrm{~K} \mathrm{~km}^{-1}(11.8 \mathrm{~K}$ in a height range of $0.6 \mathrm{~km})$ in calm wind condition indicates diminutive convection (high atmospheric static stability) and feeble thermal turbulence within $0.8 \mathrm{~km}$ (close to $900 \mathrm{mb}$ ), (2) reducing values of relative humidity in vertical profile (from $68 \%$ to $24 \%$ ) under the inversion layer depth perfectly signifying the dry warmer air is held above cold surface, (3) Sharpe turn in temperature gradient and relative humidity profile above the inversion layer, trapped dust aerosols within $1 \mathrm{~km}$ which exactly depicted in Fig. 5 as a sub dust layer, and (4) the inclusion of the moist air advection underneath of $4 \mathrm{~km}$ height have been noticed from the vertical profiles of $\mathrm{RH}$ (increased around $60 \%$ above inversion layer) and potential temperature. However, very steep variation vertically in $A B C$ (blue line in Fig. 7) from $4 \mathrm{~km} \mathrm{AGL}$ to $5.5 \mathrm{~km}$ AGL could result of low cloud. Ultimately, it cloud be acknowledge that floating dust layers (sub dust layer) has been trapped under low-level clouds (inversion layer) and persisted at almost the same height for $34 \mathrm{hrs}$ ( $23 \mathrm{hrs}$ ).

\section{Conclusions}

Severe dust storm analysis on 02 May 2018, has been carried to monitor, evaluate, and describe the aerosols activity before, during, and after a dust storm. This dust storm was a particular case because it observed that the storm had already developed before reaching IGI airport, shown in the ceilometer measurements and other ground-based observation data. From the perspective of disasters, a dust storm's sudden appearance is more dangerous than the gradually developed dust storm because of the 
minimal time for evacuation without forecast information. It is also noticed that after a dust storm, the upper dust layer remained at almost the $4 \mathrm{~km}$ height for $34 \mathrm{hrs}$. However, the sub dust layer was developed in the floating dust layer after $9 \mathrm{hrs}$ of the dust storm, remained at the almost same height. Overall, it suggested that the floating dust layer prevented from reaching the FT due to low-level clouds, and the lower layer was unable to extend above due to surface inversion.

During each dust storm, a significant increase in PM concentration observed. However, on 02 May 2018 dust storm, $\mathrm{PM}_{10}$ concentration suddenly increased (4 times over $1 \mathrm{hr}$ ), while other days, dust storms showed gradually increment. The convective and unstable conditions followed by strong wind speed (> 8 $\mathrm{m} \mathrm{s}^{-1}$ ) represented a positive correlation with each dust storm period. After dust storms, the low-level clouds did a feeble exchange of floating dust between the boundary layer and the free troposphere. This floating dust interacts with clouds and precipitates under favourable conditions. However, the partial washout of floating dust following light rain. After the severe dust storm on 02 May 2018, the residual dust layer persisted for several days within $4 \mathrm{~km}$ of height above ground level.

This study is the first report of this type of vertical distribution of dust in the dust affected area based on observation data. In a detailed analysis of aerosol-cloud interaction from the numerical simulations during the dust storm events are suggested in future studies.

\section{Declarations}

\section{ACKNOWLEDGMENTS}

We would like to thank the Director, Indian Institute of Tropical Meteorology (IITM), Pune, and Director General India Meteorological Department (IMD) for their encouragement and support during the study. The radiosonde profiles data were obtained from the University of Wyoming website (http://weather.uwyo.edu/upperair/sounding.html). The authors also acknowledge the Grandhi Mallikarjuna Rao (GMR) group and the Airports Authority of India (AAI) for their logistic support at IGI Airport New Delhi.

\section{Conflicts of interest}

The authors declared that they have no conflicts of interest to this work. We declare that we do not have any commercial or associative interest that represents a conflict of interest in connection with the work submitted.

\section{References}

1. Al-Hemoud, A., Al-Dousari, A., Misak, R., Al-Sudairawi, M., Naseeb, A., Al-Dashti, H., \& Al-Dousari, N. (2019). Economic impact and risk assessment of sand and dust storms (SDS) on the oil and gas industry in Kuwait. Sustainability (Switzerland). https://doi.org/10.3390/su11010200 
2. Albrecht, B. A. (1989). Aerosols, cloud microphysics, and fractional cloudiness. Science, 245(4923). https://doi.org/10.1126/science.245.4923.1227

3. Aryee, J. N. A., Amekudzi, L. K., Preko, K., Atiah, W. A., \& Danuor, S. K. (2020). Estimation of planetary boundary layer height from radiosonde profiles over West Africa during the AMMA field campaign: Intercomparison of different methods. Scientific African, 7. https://doi.org/10.1016/j.sciaf.2019.e00228

4. Badarinath, K. V. S., Kharol, S. K., Kaskaoutis, D. G., Sharma, A. R., Ramaswamy, V., \& Kambezidis, H. D. (2010). Long-range transport of dust aerosols over the Arabian Sea and Indian region - A case study using satellite data and ground-based measurements. Global and Planetary Change. https://doi.org/10.1016/j.gloplacha.2010.02.003

5. Blanco-Canqui, H., \& Lal, R. (2010). Principles of soil conservation and management. In Principles of Soil Conservation and Management. https://doi.org/10.1007/978-1-4020-8709-7

6. Boesenberg, J., Matthias, V., Amodeo, A., Amoiridis, V., Ansmann, A., Baldasano, J. M., Balin, I., D., B., Böckmann, C., Boselli, A., Carlsson, G., Chaikovsky, A., Chourdakis, G., Comeron, A., Tomasi, F. De, Eixmann, R., Freudenthaler, V., Giehl, H., Grigorov, I., ... Zerefos, C. (2003). EARLINET: A European Aerosol Research Lidar Network to Establish an Aerosol Climatology. Max-Planck-Institute Report.

7. Bösenberg, J., \& Hoff, R. M. (2007). Plan for the implementation of the GAW Aerosol Lidar Observation Network (GALION). World Meteorological Organization Rep. 178 (Issue 178).

8. Dey, S., Tripathi, S. N., Singh, R. P., \& Holben, B. N. (2004). Influence of dust storms on the aerosol optical properties over the Indo-Gangetic basin. Journal of Geophysical Research D: Atmospheres. https://doi.org/10.1029/2004JD004924

9. El-Askary, H., Gautam, R., Singh, R. P., \& Kafatos, M. (2006). Dust storms detection over the IndoGangetic basin using multi sensor data. Advances in Space Research. https://doi.org/10.1016/j.asr.2005.03.134

10. Gautam, R., Liu, Z., Singh, R. P., \& Hsu, N. C. (2009). Two contrasting dust-dominant periods over India observed from MODIS and CALIPSO data. Geophysical Research Letters. https://doi.org/10.1029/2008GL036967

11. Gemma Shepherd, Enric Terradellas, Alexander Baklanov, U. K., William A. Sprigg, S. N., \& Ali Darvishi Boloorani, A. A.-D. (2016). Global Assessment of Sand and Dust Storms. In UNEP.

12. Gharai, B., Jose, S., \& Mahalakshmi, D. V. (2013). Monitoring intense dust storms over the Indian region using satellite data - a case study. International Journal of Remote Sensing. https://doi.org/10.1080/01431161.2013.813655

13. Ghude, S. D., Bhat, G. S., Prabhakaran, T., Jenamani, R. K., Chate, D. M., Safai, P. D., Karipot, A. K., Konwar, M., Pithani, P., Sinha, V., Rao, P. S. P., Dixit, S. A., Tiwari, S., Todekar, K., Varpe, S., Srivastava, A. K., Bisht, D. S., Murugavel, P., Ali, K., ... Rajeevan, M. (2017). Winter fog experiment over the IndoGangetic plains of India. Current Science. https://doi.org/10.18520/cs/v112/i04/767-784

14. Ginoux, P., Prospero, J. M., Gill, T. E., Hsu, N. C., \& Zhao, M. (2012). Global-scale attribution of anthropogenic and natural dust sources and their emission rates based on MODIS Deep Blue aerosol 
products. In Reviews of Geophysics. https://doi.org/10.1029/2012RG000388

15. Goudie, A. S., \& Middleton, N. J. (2006). Desert dust in the global system. In Desert Dust in the Global System. https://doi.org/10.1007/3-540-32355-4

16. Hara, Y., Yumimoto, K., Uno, I., Shimizu, A., Sugimoto, N., Liu, Z., \& M.Winker, D. (2009). Asian dust outflow in the PBL and free atmosphere retrieved by NASA CALIPSO and an assimilated dust transport model. Atmospheric Chemistry and Physics. https://doi.org/10.5194/acp-9-1227-2009

17. Husar, R. B., Tratt, D. M., Schichtel, B. A., Falke, S. R., Li, F., Jaffe, D., Gassó, S., Gill, T., Laulainen, N. S., Lu, F., Reheis, M. C., Chun, Y., Westphal, D., Holben, B. N., Gueymard, C., McKendry, I., Kuring, N., Feldman, G. C., McClain, C., ... Malm, W. C. (2001). Asian dust events of April 1998. Journal of Geophysical Research Atmospheres. https://doi.org/10.1029/2000JD900788

18. Illingworth, A. J., Hogan, R. J., O’Connor, E. J., Bouniol, D., Brooks, M. E., Delanoë, J., Donovan, D. P., Eastment, J. D., Gaussiat, N., Goddard, J. W. F., Haeffelin, M., Klein Baltinik, H., Krasnov, O. A., Pelon, J., Piriou, J. M., Protat, A., Russchenberg, H. W. J., Seifert, A., Tompkins, A. M., ... Wrench, C. L. (2007). Cloudnet: Continuous evaluation of cloud profiles in seven operational models using ground-based observations. Bulletin of the American Meteorological Society, 88(6), 883-898. https://doi.org/10.1175/BAMS-88-6-883

19. Jugder, D., Shinoda, M., Kimura, R., Batbold, A., \& Amarjargal, D. (2014). Quantitative analysis on windblown dust concentrations of PM10 (PM2.5) during dust events in Mongolia. Aeolian Research. https://doi.org/10.1016/j.aeolia.2014.04.005

20. Kaskaoutis, D. G., Kosmopoulos, P. G., Nastos, P. T., Kambezidis, H. D., Sharma, M., \& Mehdi, W. (2012). Transport pathways of Sahara dust over Athens, Greece as detected by MODIS and TOMS. Geomatics, Natural Hazards and Risk. https://doi.org/10.1080/19475705.2011.574296

21. Kawai, K., Kai, K., Jin, Y., Sugimoto, N., \& Batdorj, D. (2018). Lidar network observation of dust layer development over the gobi desert in association with a cold frontal system on 22-23 may 2013. Journal of the Meteorological Society of Japan. https://doi.org/10.2151/jmsj.2018-023

22. Kawai, K., Nishio, Y., Kai, K., Noda, J., Munkhjargal, E., Shinoda, M., Sugimoto, N., Shimizu, A., Davaanyam, E., \& Batdorj, D. (2019). Ceilometer observation of a dust event in the Gobi Desert on 2930 April 2015: Sudden arrival of a developed dust storm and trapping of dust within an inversion layer. Scientific Online Letters on the Atmosphere. https://doi.org/10.2151/SOLA.2019-011

23. Kayetha, V. K., Senthilkumar, J., Prasad, A. K., Cervone, G., \& Singh, R. P. (2007). Effect of dust storm on ocean color and snow parameters. Journal of the Indian Society of Remote Sensing. https://doi.org/10.1007/BF02991828

24. Kedia, S., \& Ramachandran, S. (2011). Seasonal variations in aerosol characteristics over an urban location and a remote site in western India. Atmospheric Environment. https://doi.org/10.1016/j.atmosenv.2011.01.040

25. Kohfeld, K. E., \& Harrison, S. P. (2001). DIRTMAP: The geological record of dust. Earth-Science Reviews. https://doi.org/10.1016/S0012-8252(01)00042-3 
26. Kumar, S., Kumar, S., Kaskaoutis, D. G., Singh, R. P., Singh, R. K., Mishra, A. K., Srivastava, M. K., \& Singh, A. K. (2015). Meteorological, atmospheric and climatic perturbations during major dust storms over Indo-Gangetic Basin. Aeolian Research. https://doi.org/10.1016/j.aeolia.2015.01.006

27. Mahowald, N. M., Kloster, S., Engelstaedter, S., Moore, J. K., Mukhopadhyay, S., McConnell, J. R., Albani, S., Doney, S. C., Bhattacharya, A., Curran, M. A. J., Flanner, M. G., Hoffman, F. M., Lawrence, D. M., Lindsay, K., Mayewski, P. A., Neff, J., Rothenberg, D., Thomas, E., Thornton, P. E., \& Zender, C. S. (2010). Observed 20th century desert dust variability: Impact on climateand biogeochemistry. Atmospheric Chemistry and Physics. https://doi.org/10.5194/acp-10-10875-2010

28. McGowan, H. A., \& Soderholm, J. (2012). Laser ceilometer measurements of Australian dust storm highlight need for reassessment of atmospheric dust plume loads. Geophysical Research Letters, 39(2). https://doi.org/10.1029/2011GL050319

29. Middleton, N. J. (2017). Desert dust hazards: A global review. In Aeolian Research. https://doi.org/10.1016/j.aeolia.2016.12.001

30. Miller, R. L., Tegen, I., \& Perlwitz, J. (2004). Surface radiative forcing by soil dust aerosols and the hydrologic cycle. Journal of Geophysical Research: Atmospheres, 109(4).

https://doi.org/10.1029/2003jd004085

31. Miri, A., Ahmadi, H., Ekhtesasi, M. R., Panjehkeh, N., \& Ghanbari, A. (2009). Environmental and socioeconomic impacts of dust storms in Sistan Region, Iran. International Journal of Environmental Studies. https://doi.org/10.1080/00207230902720170

32. Mona, L., Liu, Z., Müller, D., Omar, A., Papayannis, A., Pappalardo, G., Sugimoto, N., \& Vaughan, M. (2012). Lidar measurements for desert dust characterization: An overview. In Advances in Meteorology. https://doi.org/10.1155/2012/356265

33. Münkel, C., Eresmaa, N., Räsänen, J., \& Karppinen, A. (2007). Retrieval of mixing height and dust concentration with lidar ceilometer. Boundary-Layer Meteorology. https://doi.org/10.1007/s10546006-9103-3

34. Murayama, T., Sugimoto, N., Uno, I., Kinoshita, K., Aoki, K., Hagiwara, N., Liu, Z., Matsui, I., Sakai, T., Shibata, T., Arao, K., Sohn, B. J., Won, J. G., Yoon, S. C., Li, T., Zhou, J., Hu, H., Abo, M., lokibe, K., ... Iwasaka, Y. (2001). Ground-based network observation of Asian dust events of April 1998 in east Asia. Journal of Geophysical Research Atmospheres. https://doi.org/10.1029/2000JD900554

35. Nemuc, A., Stachlewska, I. S., Vasilescu, J., Górska, A., Nicolae, D., \& Talianu, C. (2014). Optical properties of long-range transported volcanic ash over Romania and Poland during Eyjafjallajökull eruption in 2010. Acta Geophysica. https://doi.org/10.2478/s11600-013-0180-7

36. Pai, D. S., Nair, S. A., \& Ramanathan, A. N. (2013). Long term climatology and trends of heat waves over India during the recent 50 years (1961-2010). Mausam, 64(4).

37. Pandey, S. K., Vinoj, V., Landu, K., \& Babu, S. S. (2017). Declining pre-monsoon dust loading over South Asia: Signature of a changing regional climate. Scientific Reports. https://doi.org/10.1038/s41598-017-16338-w 
38. Pandithurai, G., Dipu, S., Dani, K. K., Tiwari, S., Bisht, D. S., Devara, P. C. S., \& Pinker, R. T. (2008). Aerosol radiative forcing during dust events over New Delhi, India. Journal of Geophysical Research Atmospheres. https://doi.org/10.1029/2008JD009804

39. Parde, A. N., Ghude, S. D., Pithani, P., Dhangar, N. G., Nivdange, S., Krishna, G., Lal, D. M., Jenamani, R., Singh, P., Jena, C., Karumuri, R., Safai, P. D., \& Chate, D. M. (2019). Estimation of Surface Particulate Matter (PM2.5 and PM10) Mass Concentration from the Ceilometer Backscattered Profiles. Aerosol and Air Quality Research. https://doi.org/10.4209/aaqr.2019.08.0371

40. Patil, M. N., Patil, S. D., Waghmare, R. T., \& Dharmaraj, T. (2013). Planetary Boundary Layer height over the Indian subcontinent during extreme monsoon years. Journal of Atmospheric and SolarTerrestrial Physics, 92. https://doi.org/10.1016/j.jastp.2012.10.011

41. Prasad, A. K., \& Singh, R. (2007a). Changes in Himalayan snow and glacier cover between 1972 and 2000. Eos, 88(33), 326. https://doi.org/10.1029/2007E0330002

42. Prasad, A. K., \& Singh, R. P. (2007b). Changes in aerosol parameters during major dust storm events (2001-2005) over the Indo-Gangetic Plains using AERONET and MODIS data. Journal of Geophysical Research Atmospheres. https://doi.org/10.1029/2006JD007778

43. Prospero, J. M., Ginoux, P., Torres, O., Nicholson, S. E., \& Gill, T. E. (2002). Environmental characterization of global sources of atmospheric soil dust identified with the Nimbus 7 Total Ozone Mapping Spectrometer (TOMS) absorbing aerosol product. Reviews of Geophysics. https://doi.org/10.1029/2000RG000095

44. Ramanathan, V., Crutzen, P. J., Kiehl, J. T., \& Rosenfeld, D. (2001). Atmosphere: Aerosols, climate, and the hydrological cycle. In Science. https://doi.org/10.1126/science.1064034

45. Sarkar, S., Chauhan, A., Kumar, R., \& Singh, R. P. (2019). Impact of Deadly Dust Storms (May 2018) on Air Quality, Meteorological, and Atmospheric Parameters Over the Northern Parts of India. GeoHealth. https://doi.org/10.1029/2018gh000170

46. Sikka, D. R. (1997). Desert climate and its dynamics. Current Science.

47. Sivaprasad, P., Babu, C. A., Samah, A. A., \& Jayakrishnan, P. R. (2017). An analysis on the dust aerosol climatology over the major dust sources in the northern hemisphere. Arabian Journal of Geosciences, 10(19). https://doi.org/10.1007/s12517-017-3191-x

48. Twomey, S. (1977). The Influence of Pollution on the Shortwave Albedo of Clouds. Journal of the Atmospheric Sciences, 34(7). https://doi.org/10.1175/1520-0469(1977)034<1149:tiopot>2.0.co;2

49. Uno, I., Eguchi, K., Yumimoto, K., Takemura, T., Shimizu, A., Uematsu, M., Liu, Z., Wang, Z., Hara, Y., \& Sugimoto, N. (2009). Asian dust transported one full circuit around theglobe. Nature Geoscience. https://doi.org/10.1038/ngeo583

50. Verma, S., Payra, S., Gautam, R., Prakash, D., Soni, M., Holben, B., \& Bell, S. (2013). Dust events and their influence on aerosol optical properties over Jaipur in Northwestern India. Environmental Monitoring and Assessment. https://doi.org/10.1007/s10661-013-3103-9

51. Welton, E. J., Campbell, J. R., Spinhirne, J. D., \& Scott III, V. S. (2001). Global monitoring of clouds and aerosols using a network of micropulse lidar systems. Lidar Remote Sensing for Industry and 
Environment Monitoring, 4153, 151. https://doi.org/10.1117/12.417040

52. World Health Organization. (2013). Review of evidence on health aspects of air pollution REVIHAAP Project: Technical Report. In World Health Organization.

https://doi.org/10.1007/BF00379640

\section{Figures}

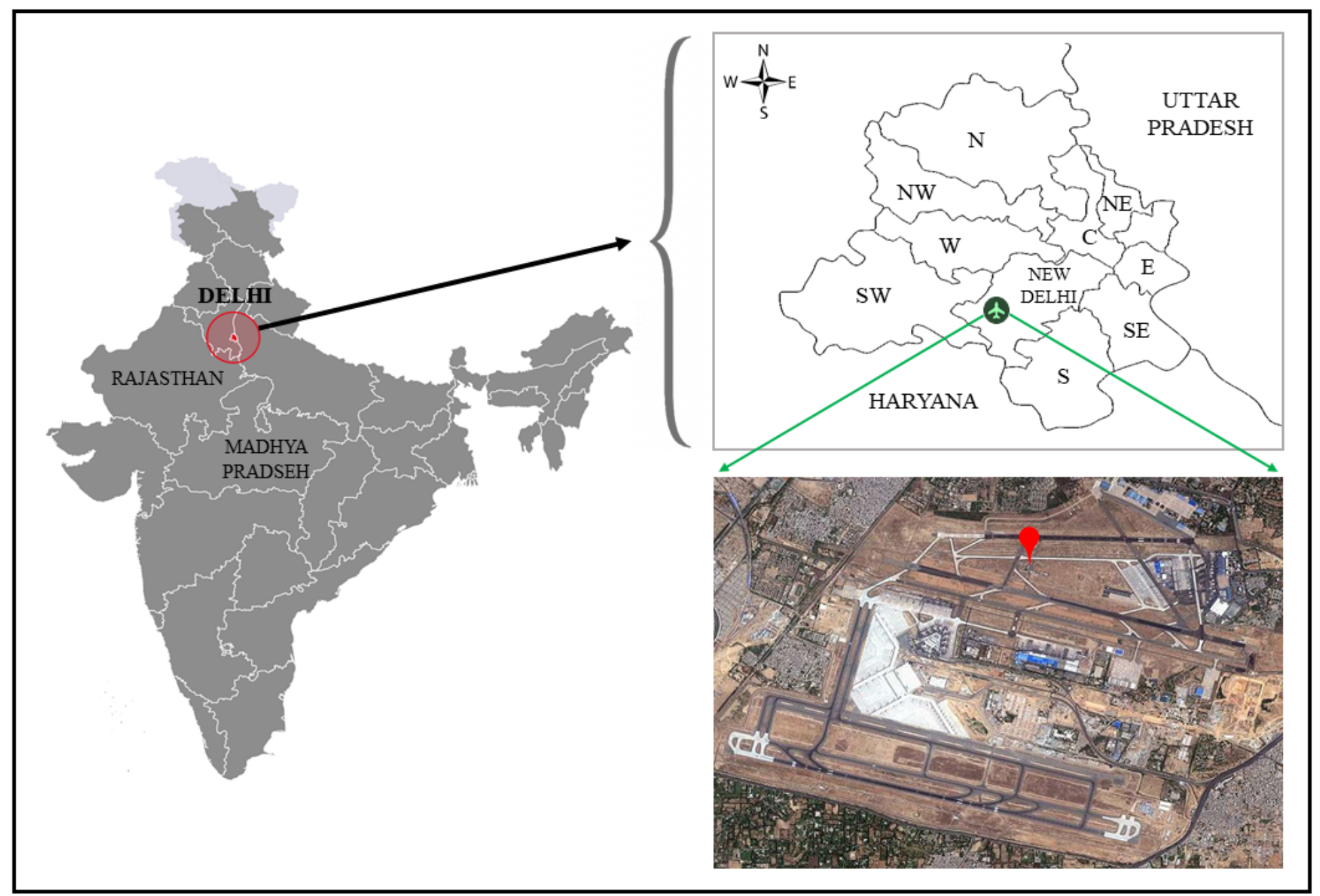

Figure 1

The geographical location of Delhi is highlighted by a red circle on the map of India, and a red symbol remarks an observational site (IGI airport, New Delhi, India) on Google satellite image. Note: The designations employed and the presentation of the material on this map do not imply the expression of any opinion whatsoever on the part of Research Square concerning the legal status of any country, territory, city or area or of its authorities, or concerning the delimitation of its frontiers or boundaries. This map has been provided by the authors. 

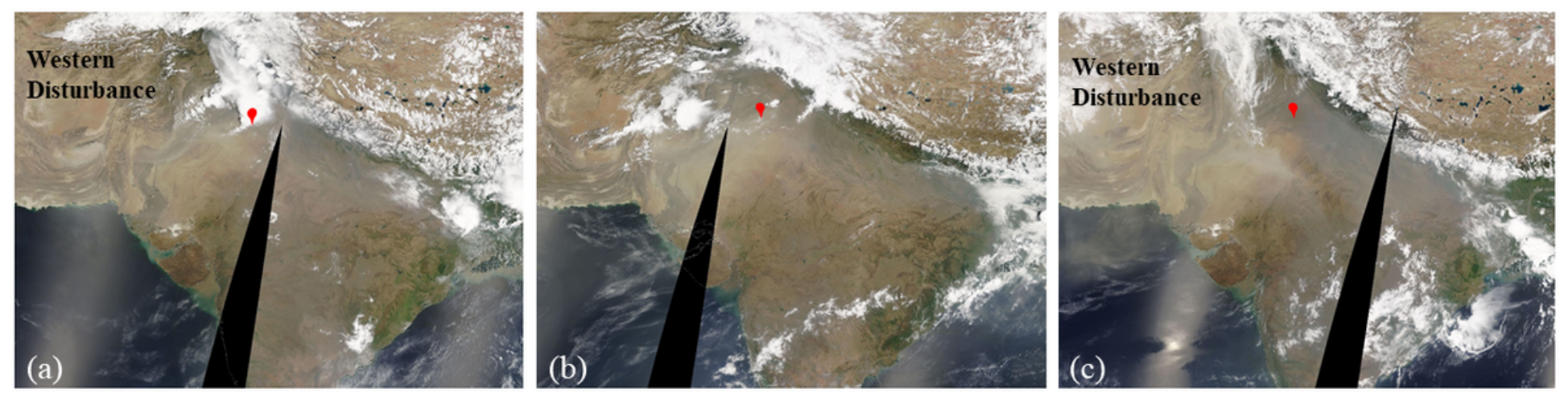

\section{Figure 2}

MODIS Terra corrected reflectance imagery of dust concentration and its transport over Indo-Gangetic Plain for (a) 02 May, (b) 07 May, and (c) 13 May in 2018 and red dot represent the observational site. Note: The designations employed and the presentation of the material on this map do not imply the expression of any opinion whatsoever on the part of Research Square concerning the legal status of any country, territory, city or area or of its authorities, or concerning the delimitation of its frontiers or boundaries. This map has been provided by the authors.

(a)

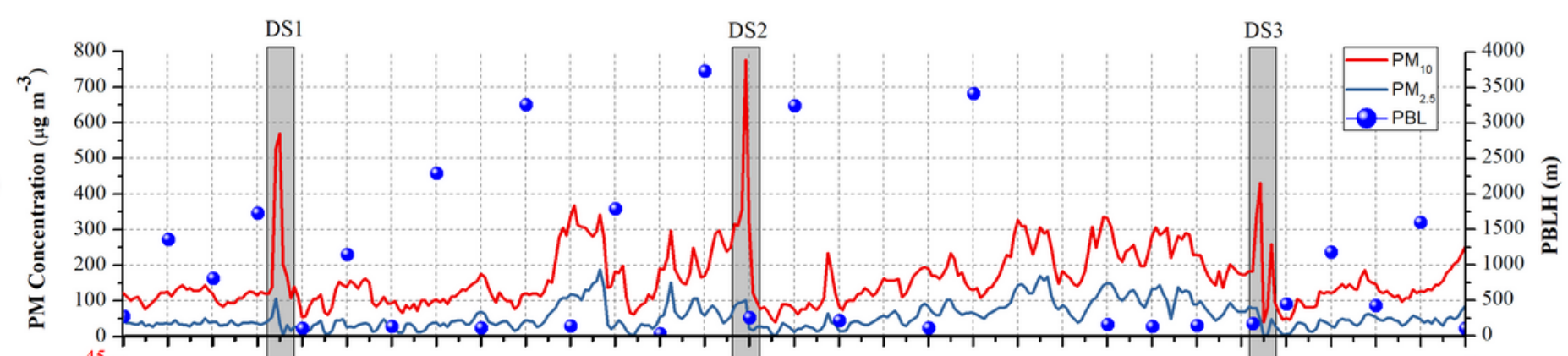

(b)

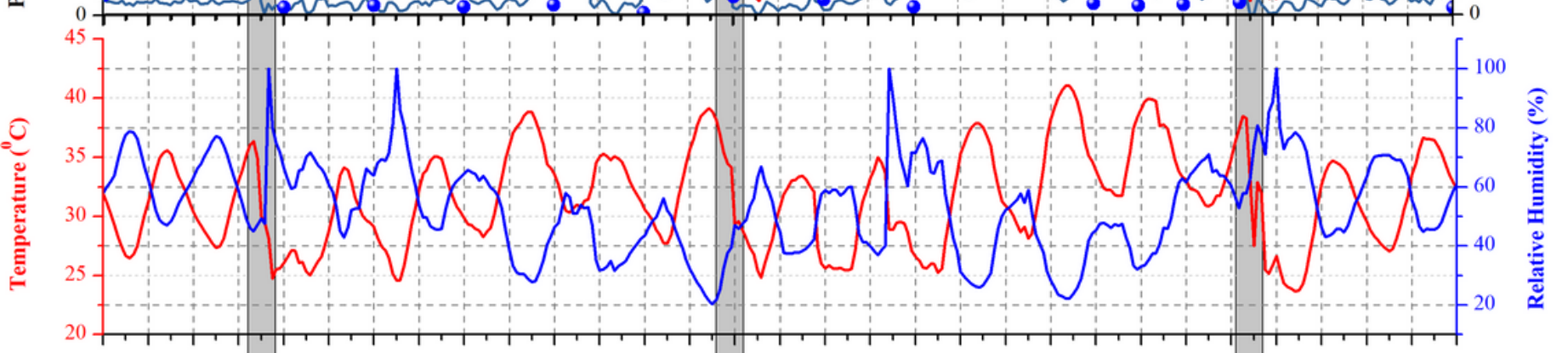

(c)

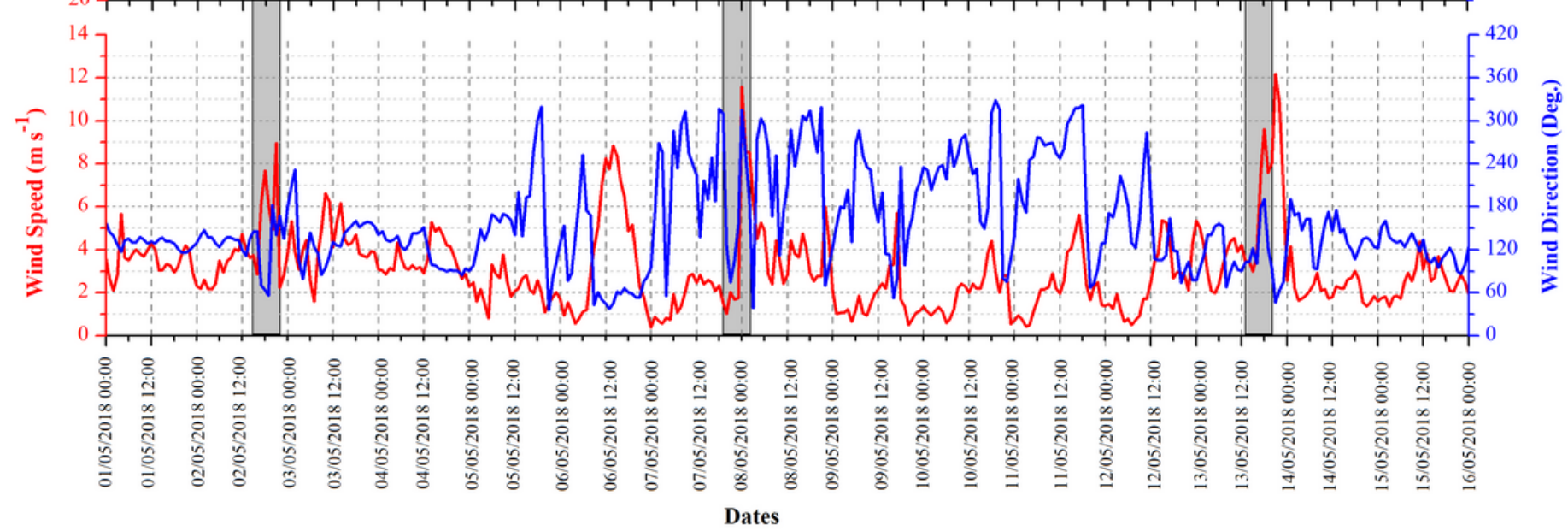




\section{Figure 3}

The temporal variation of the surface meteorological parameters from 01 May 2018 to 16 May 2018.at the IGI airport, New Delhi, India. (a) PM10 and PM2.5 mass concentrations along with PBLH derived from radiosonde at two available time step, (b) air temperature and relative humidity, and (c) wind speed and wind direction. The shaded areas represent the three dust storm activity periods.

(a)

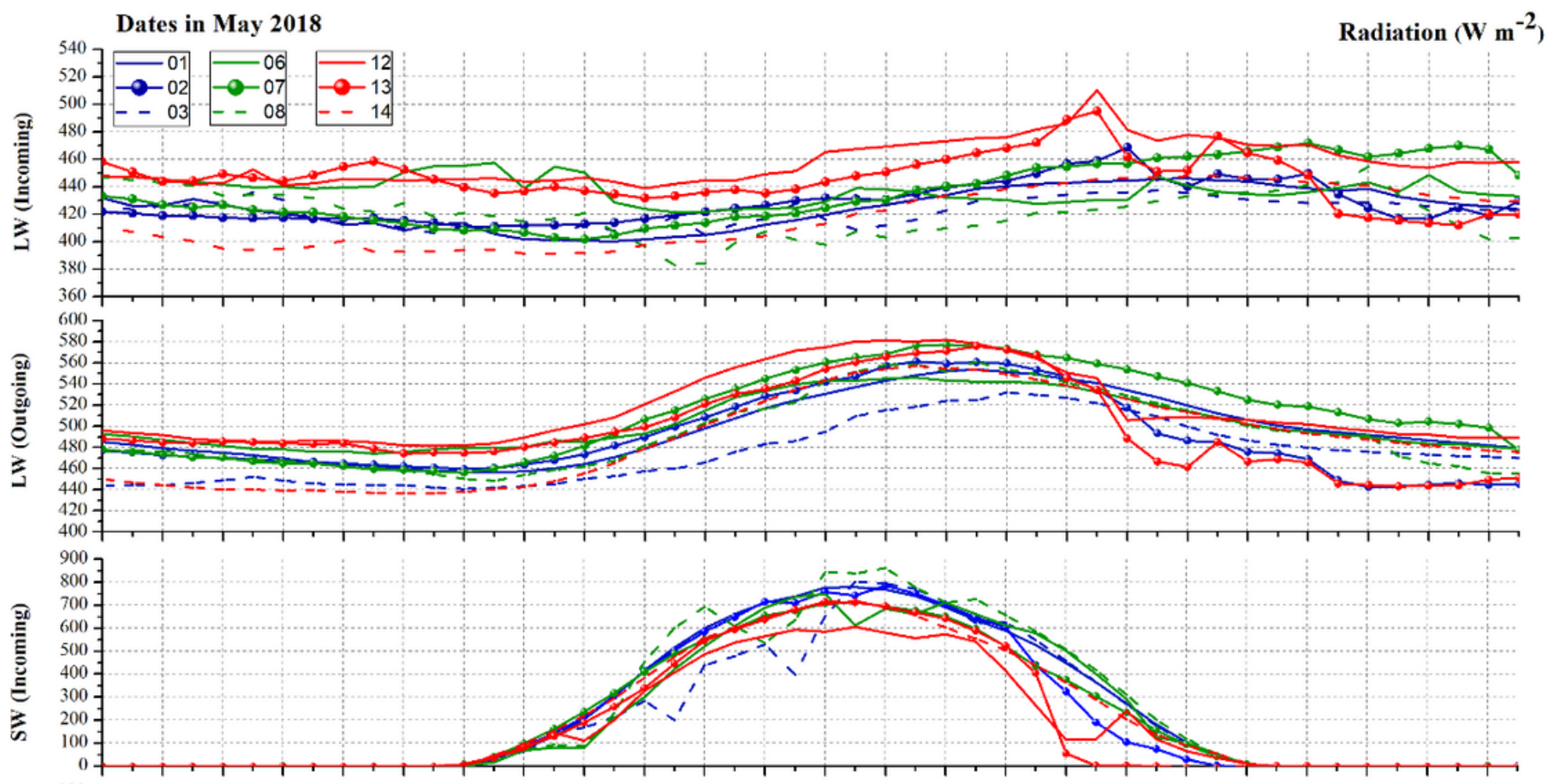

(d)

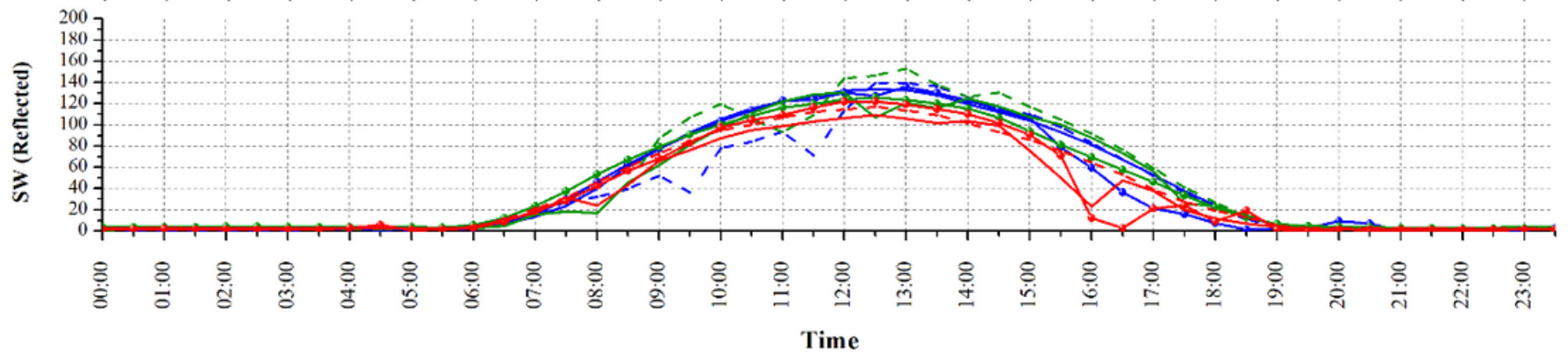

\section{Figure 4}

Temporal variation of the surface radiative fluxes at (a) Incoming longwave, (b) Outgoing longwave, (c) Incoming shortwave and (d) Reflected shortwave regions from 01 May 2018 to 16 May 2018.at the IGI airport, New Delhi, India. 


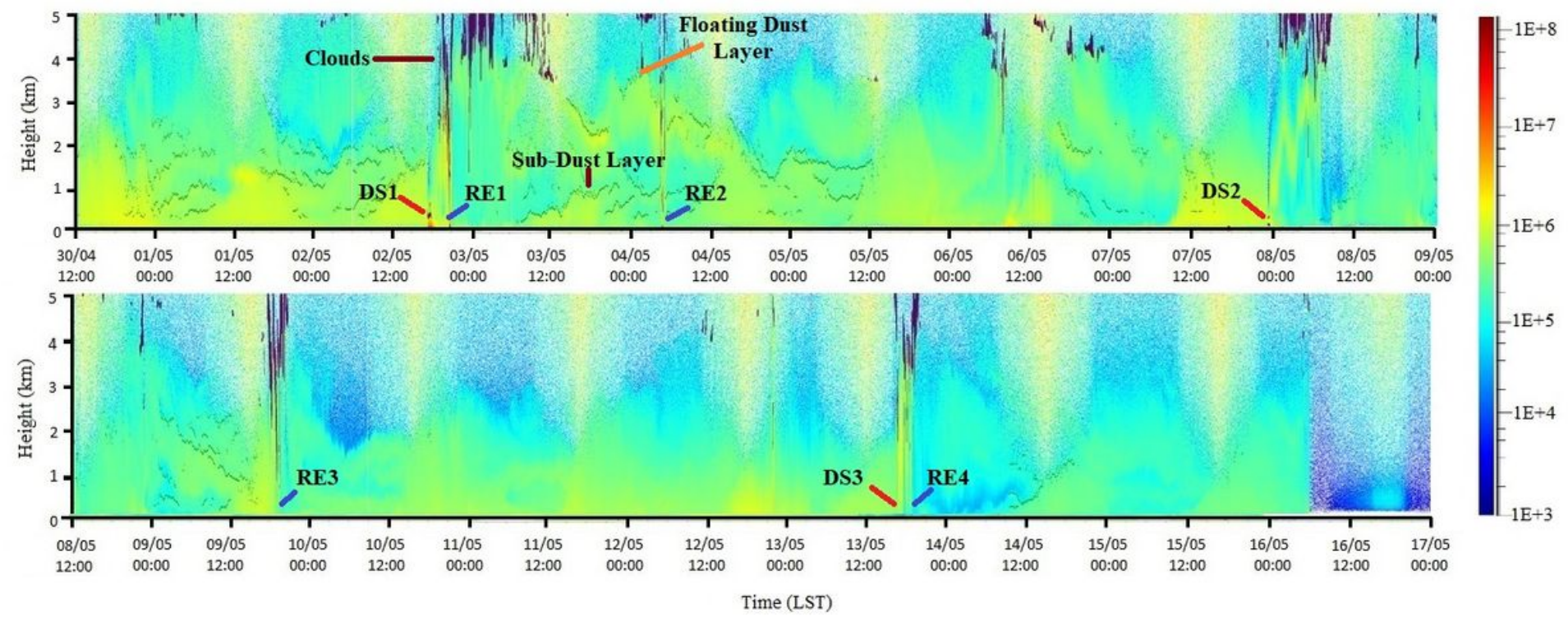

\section{Figure 5}

The temporal evolution of attenuated backscatter signal from the ground to a height of $5 \mathrm{~km} \mathrm{AGL}$ observed by the CHM 15k Nimbus ceilometer. Three dust storm events represent by letter DS1, DS2, and DS3 and corresponding scatter rainfall events represent by RF1, RF2, RF3, and RF4, respectively. 
(a)

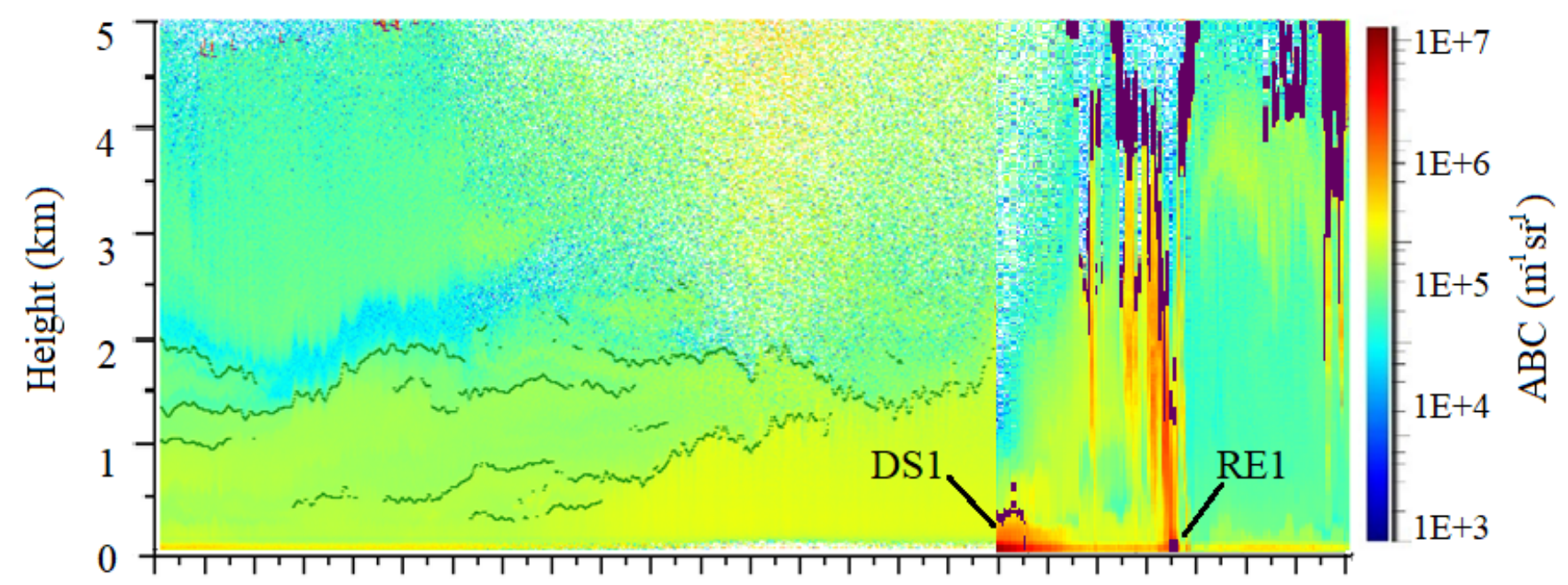

(b)

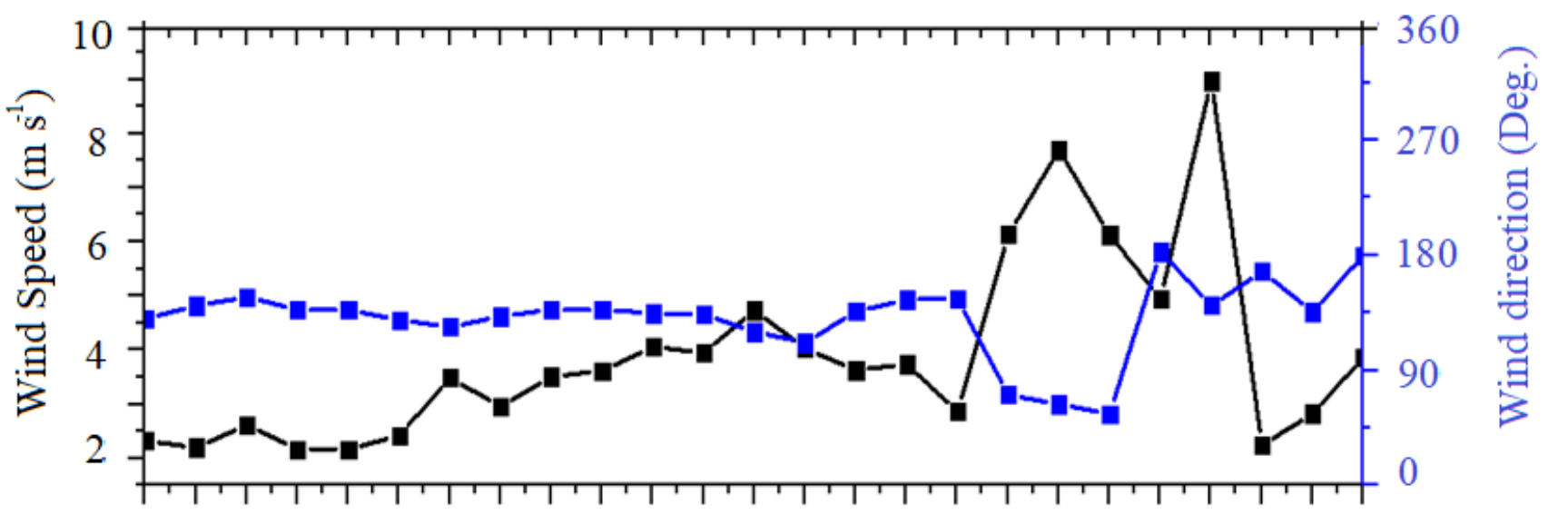

(c)

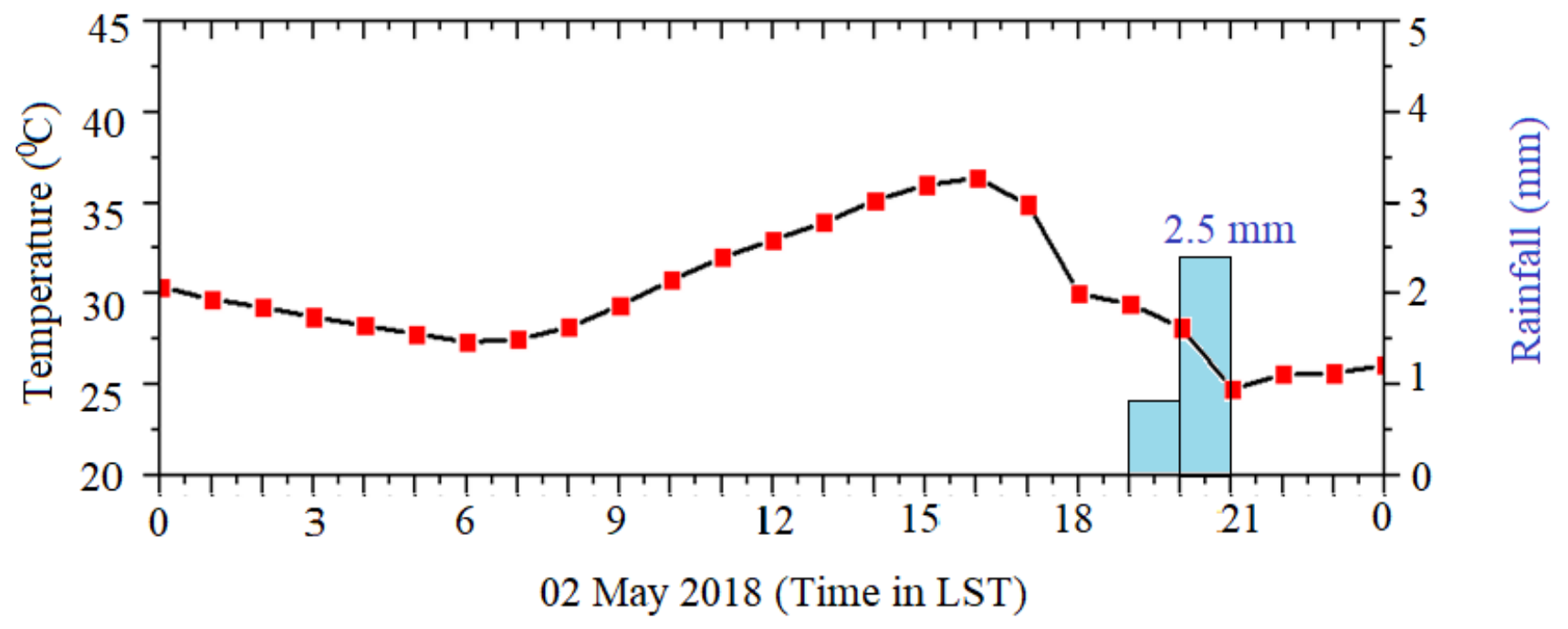

Figure 6

Ground-based observational data at the IGI airport, Delhi, India, on 02 May 2018. (a) Time-height crosssection of attenuated backscatter coefficient. (b) Time series of hourly averaged wind vector, and (c) temperature and rainfall from the multi-component weather sensors WXT 520. 


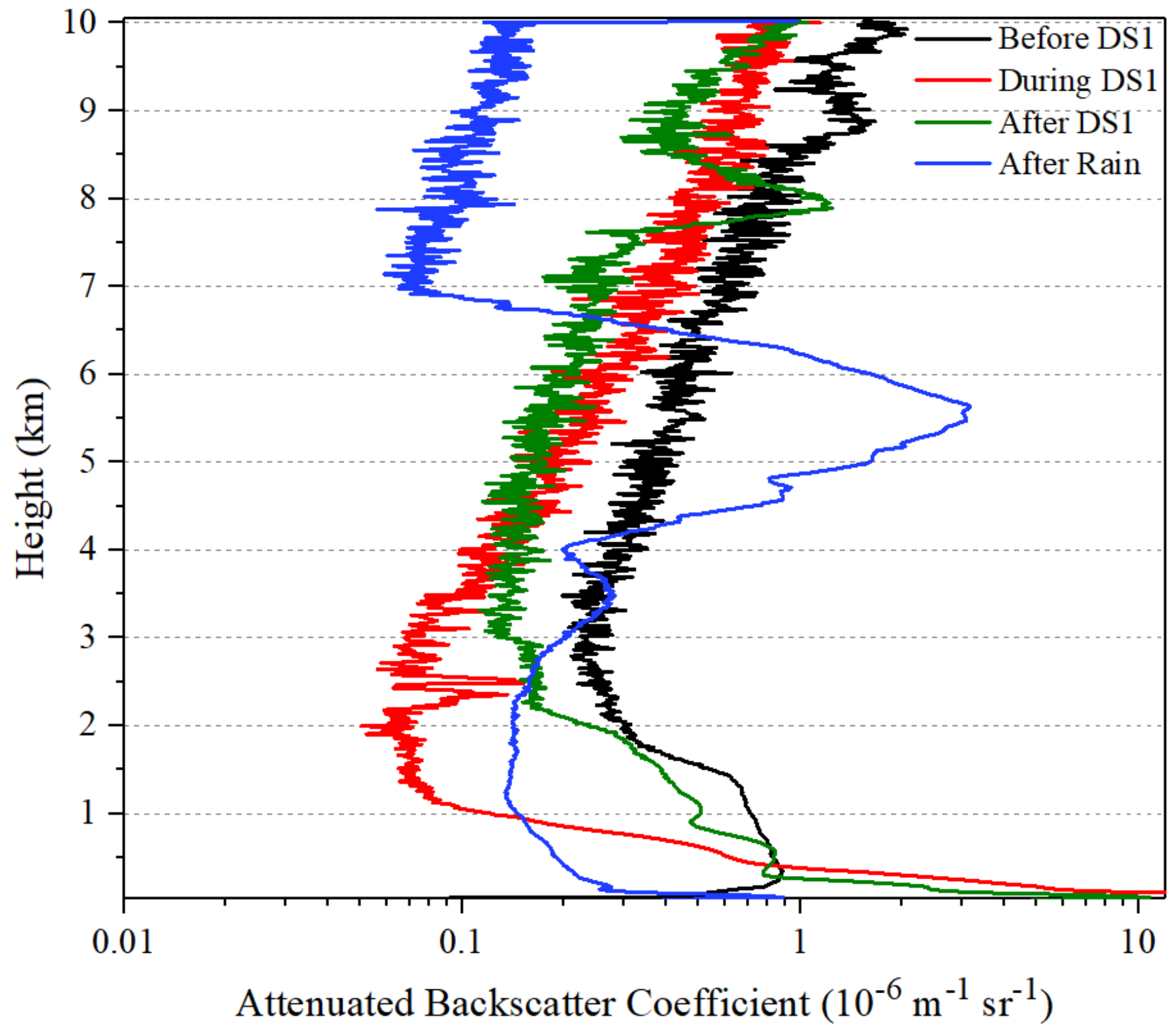

Figure 7

Variations in the ceilometer based vertical backscatter profiles during 02 May 2018 dust storm at IGI airport, New Delhi, India. 

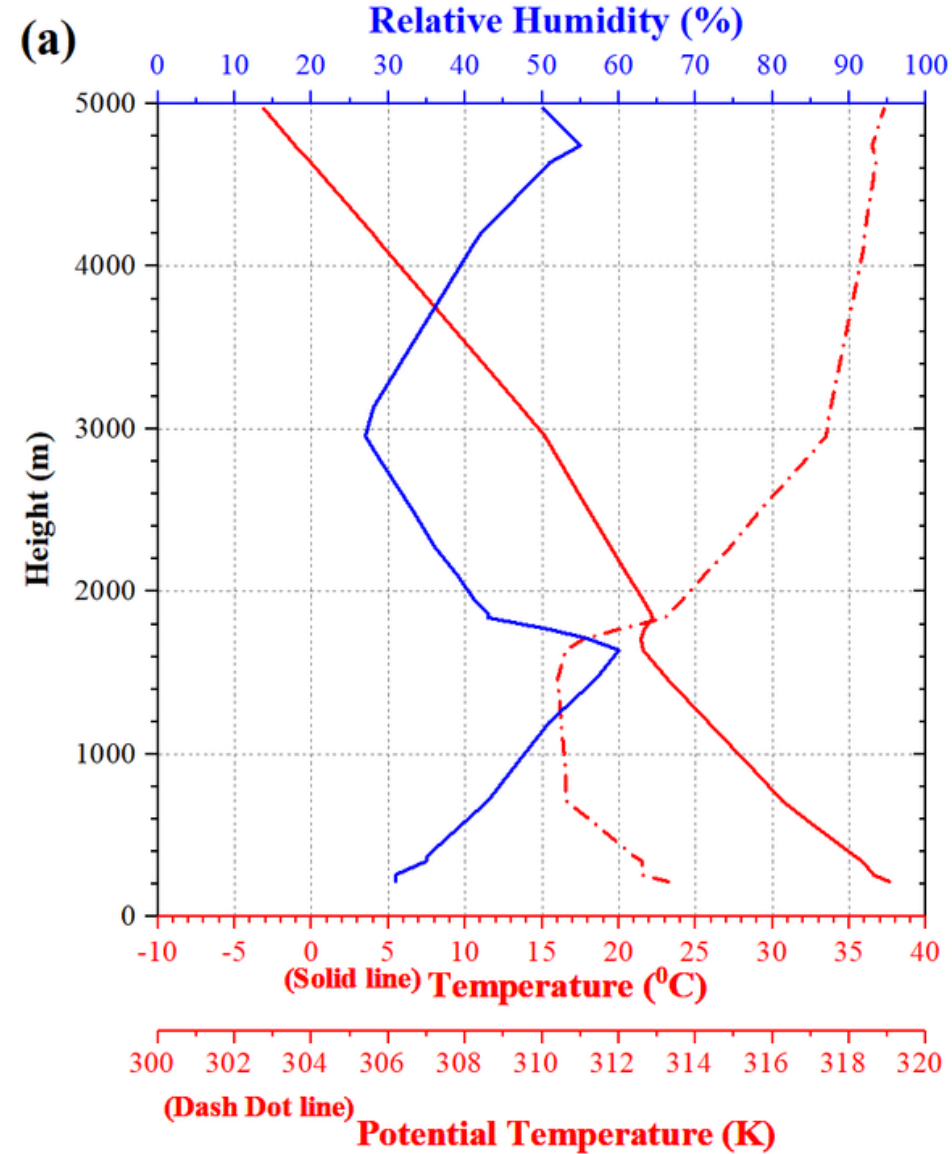

(b)

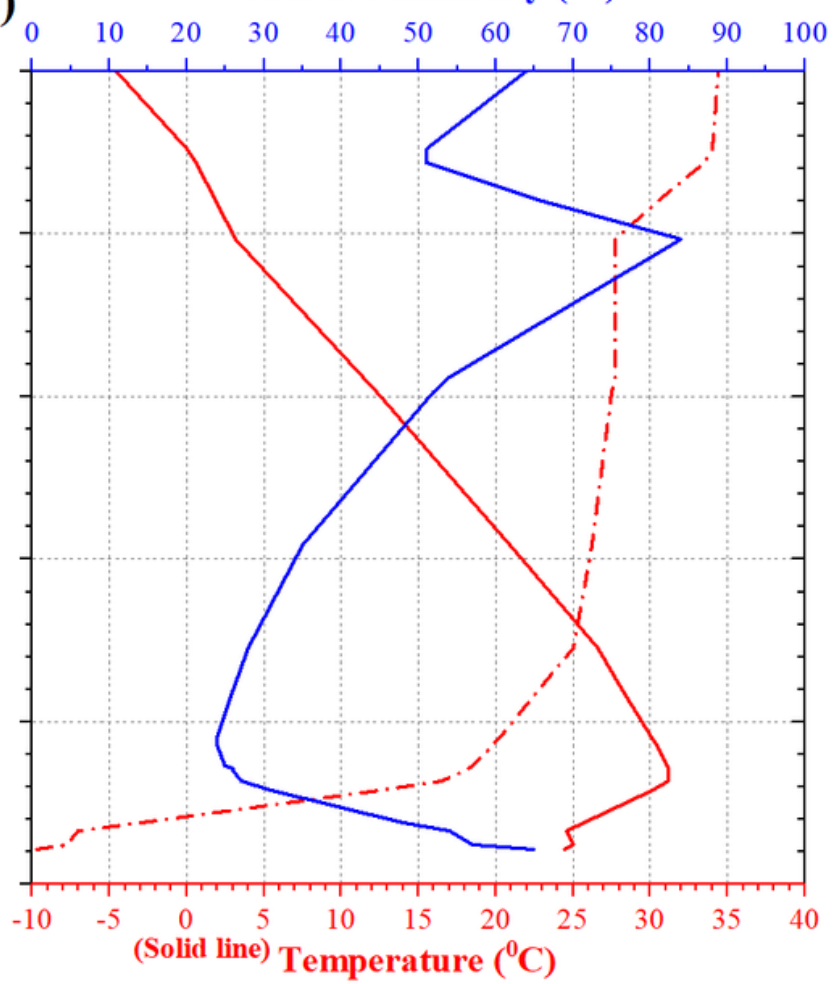

$\begin{array}{lllllllllll}300 & 302 & 304 & 306 & 308 & 310 & 312 & 314 & 316 & 318 & 320\end{array}$

(Dash Dot line) Potential Temperature (K)

\section{Figure 8}

Vertical profiles of temperature, potential temperature, and relative humidity from radiosonde observation at the Indian Meteorological Department (IMD), New Delhi station. (a) Data are referred to (a) 17:30 LST on 02 May 2018, and (b) 05:30 LST on 03 May 2018. 